\title{
EHD1 wt Allele
}

National Cancer Institute

\section{Source}

National Cancer Institute. EHD1 wt Allele. NCI Thesaurus. Code C126474.

Human EHD1 wild-type allele is located in the vicinity of $11 \mathrm{q} 13$ and is approximately $37 \mathrm{~kb}$ in length. This allele, which encodes EH domain-containing protein 1, plays a role in endocytic recycling. 